\title{
Review on Genetically Modified Horticultural Crops, Benefit, Risk and Public Perceptions
}

\author{
Kifle Zerga \\ Wolkite University, Department of Horticulture
}

\begin{abstract}
Since agriculture started Peoples were trying to select the best varieties, cross-fertilize and then further selecting to improve the domesticated crops. Through process, plant improvement by the use of biotechnology and genetic engineering by manipulating existing genetic resources started. This technology offers breeders access short way of improving domesticated plants, mainly because it can bypass biological barriers for recombination and genetic exchange across unrelated species by creating Trans genes. The first genetically modified (GM) plant was produced in 1983, using an antibiotic-resistant tobacco plant, since then a number of genetically modified food crops were developed. Some of the genetically modified crops available in the market include cotton, soybean, canola, potatoes, corn, tomatoes, etc. This paper critically reviews genetically modified crops, their benefit, risk and public perception, it also addresses the production trend of biotech crops. Genetically-modified food crops has the potential to solve many of the world's hunger and malnutrition problems and to help protect and preserve the environment by increasing yield and reducing reliance upon chemical pesticides and herbicides. In contrary much has been said about potential risks of genetic engineering technology, there are critics and concerns about the safety, environmental and ecological risks and health hazards; but so far there is little evidence from scientific studies that these risks are real. The following points are the gaps need to be filled in order for it to be successful technology. This includes to test the potential risks of GM food crops under controlled condition before their introduction, Scientists should first finish probing for desirable trait from more of related species before going for another organism so as to reduce the public's concern, informing the public about the food production and the safety used in developing GM crops so they can form opinions based on facts, not fear, making the primary goal of institution to serve the public not money.
\end{abstract}

DOI: $10.7176 /$ ALST/74-01

Publication date:May $31^{\text {st }} 2019$

\section{INTRODUCTION}

Agriculture started more than 10,000 years ago when humans moved from being hunters and gatherers towards organized societies with food producers and consumers; Initially wild plant species were domesticated by choosing those variants that had good properties (e.g., yield, reliability, lack of toxins and ease of cultivation), and this was followed by a long period of time in which farmers undertook empirical crop breeding by selecting the best variants, cross-fertilizing them and then further selecting to improve them (George et al,2009).

And now in the light of mounting population pressures and rising quality-of-life expectations, food systems are challenged to meet current global needs and for the upcoming future. In undeveloped and developing countries, enormous increase in population has resulted in poverty, food insecurity, and poor nutrition among the masses. Advances in scientific discovery and laboratory techniques have led to the ability of plant improvement through the use of biotechnology and genetic engineering by manipulating existing genetic resources (Singh, 2006).

The introduction of genetically modified (GM) crops has been a major technological advance to world agriculture over the last few decades. It has been shown that this technology has the potential to help increase world food production at a time of rapid change(George et al,2009). Genetic engineering offers plant breeders access to an infinitely wide array of novel genes and traits, which can be inserted through a single event into high-yielding and locally-adapted cultivars (Sharma et al, 2002). Genetic engineering techniques now allow us to transfer the genes of one species over to another species. These techniques can be applied generally to all living species: bacteria, fungi, viruses, animals, and plants. After undergoing genetic engineering, the organisms are referred to as genetically modified organisms (GMOs) to indicate that they are organisms that have had their genetic profile altered in a laboratory (Job, 2002).

However, in recent years, the use and release of genetically modified organisms (GMOs) has been an issue of intense public concern and, in the case of foods, products containing GMOs thereof carry the risk of consumer rejection (José and Jordi, 2011). The current social debate is based on the fact that these new transplanted characters can originate from a species totally unrelated to the receiving plant (Job, 2002).These concerns are divided into different categories, namely: health, nutritional, environmental, ecological, socioeconomic, and ethical concerns (Nigel and Peter, 2000). These concerns include those arising due to GM plants properties themselves, those resulting from the spread of the Trans genes to other organisms, and also those resulting from their release into the environment (Smita, 2013). 
Due to this GM biosafety regulation laws have been passed in most industrialized countries and in an increasing number of developing countries (George et al, 2009).Evaluations for each GM crop or trait have been conducted using different feeding periods, animal models, and parameters in different countries (Joséa and Jordi, 2011).So far, many researches were done to study the benefit, risk and community perception of GMO's from different perspectives in many parts of the world. Numerous types of surveys were also conducted on national and cross-national levels to make sure that the community has accepted the products fully and the products are risk free (Hamstra, 1998). However, these efforts made so far are not well documented and readily available to the readers for further investigation and disseminating information regarding GMO's. Therefore, the objective of this seminar paper is to review and document available research works done on genetically modified crops, their benefit, and risk and community perception.

\subsection{Objective}

To Review Genetically Modified Horticultural Crops, Benefit, Risk and Public Perceptions

\subsection{Review Methodology}

This review paper was prepared from different sources, majorly from different books, journals and proceedings in the library and internet.

\section{LITERATURE REVIEW}

\subsection{History of GMOs}

Taking the advantage of the universality of the genetic code, researchers have succeeded to associate DNA sequences coming from different organisms using molecular biology techniques and to integrate foreign DNA within plants. These genetically-modified organisms (the so called GMOs) have the ability to synthesize some additional proteins which confer new properties on them(Gachet et al,1998).In addition it is potentially a short way to improving domesticated plants and animals, mainly because it can bypass biological barriers for recombination and genetic exchange across unrelated species by creating transgenes (Arne,2009).

The introduction of GMO technology has been hailed as a gene revolution similar to the green revolution of the 1950s when scientists discovers the genetic material can be transferred between species (Pingali and Raney, 2005). The first genetically modified (GM) plant was produced in 1983, using an antibiotic-resistant tobacco plant. China was the first country to commercialize a transgenic crop in the early 1990s with the introduction of virus resistant tobacco. In 1994, the transgenic 'Flavour Saver tomato' was approved by the Food and Drug Administration (FDA) for marketing in the USA. The modification allowed the tomato to delay ripening after picking. In 1995, few transgenic crops received marketing approval. This include canola with modified oil composition (Calgene), Bacillus thuringiensis (Bt) corn/maize (Ciba-Geigy), cotton resistant to the herbicide bromoxynil (Calgene), Bt cotton (Monsanto), Bt potatoes (Monsanto), soybeans resistant to the herbicide glyphosate (Monsanto), virus-resistant squash (Asgrow) and additional delayed ripening tomatoes (Clive, 2011). As of 2011, the USA leads a list of multiple countries in the production of GM crops. Currently, there are a number of food species in which a genetically modified version exists (Johnson 2008). Some of the foods that are available in the market include cotton, soybean, canola, potatoes, eggplant, strawberries, corn, tomatoes, lettuce, cantaloupe, carrots etc.

\subsection{Genetic manipulation (gm) technology}

This technology is also called genetic engineering, recombinant DNA technology and bioengineering among other terms and for over the last three decades, advances in the ability to manipulate DNA have led to ways of bypassing the main limitation of plant breeding that of lack of suitable genes in sexually compatible species); and it has been defined as: a technology in which a gene or genes are taken from one organism (the donor) or are synthesized de novo, possibly modified and then inserted into another organism (the recipient) in an attempt to transfer a desired trait or character( George et al,2009).

Genetic manipulation involves finding an organism that naturally possesses a desired trait. The DNA is taken from the selected organism, and the desired gene is copied from the extracted genes. This is called gene cloning. It is possible to modify the gene a little in a more preferable way once it is placed inside the recipient. The next process is transformation, which involves delivering the Transgene (the new gene) into the cells of the recipient organism.

There are several techniques for introducing genes into plant chromosomes. The available transformation techniques include direct transfer of gene such as Biolistic, Electroporation, Direct uptake in protoplasts, Microinjection, and Indirect transfer of gene such as Agro bacterium-mediated transformation. Biolistic and Agrobacterium are the most widely used techniques (George et al, 2009).

\subsubsection{Agro bacteriumTumefaciens}

Agro bacterium tumefaciens is a plant pathogenic bacterium that contains a plasmid (the tumour-inducing or Ti 
plasmid), part of which (the T-DNA) integrates into the host plant chromosomes; it has been termed "nature's genetic engineer". For plant transformation, the tumour-inducing genes are removed to make a "disarmed" plasmid. The GOI is placed between the left and right borders of the T-DNA which is then reintroduced into Agrobacterium. This Agrobacterium is then co-cultivated with suitable target cells (embryogenic suspensions or callus) to enable the modified T-DNA to integrate into the cells. After removal of the Agrobacterium, the transformed cells are grown into plants under selection.

\subsubsection{Biolistic transformations (Particle Bombardment)}

The biolistic procedure, also known as the "gene gun", involves firing small metal particles coated with the construct DNA into plant cells be used for transformation. The metal particles, usually gold or tungsten, are accelerated to high speed by the rapid release of high pressure helium in the gene gun into the target cells. The target is tot potent cells(George et al, 2009). The major factor limit in the use of biolistic transformation is that it often results in insertion of multiple copies of the introduced genes at multiple sites within genome, which lead to gene silencing or altered gene expression (Rivera et al., 2012).

\subsection{Conventional Breeding vs. GMO}

Farmers and plant-breeders have been changing the genes of crop plants for thousands of years, developing plant varieties expressing good agronomic characteristics making their ultimate goal. Even though the two technologies are very similar, genetic modification differs from conventional plant breeding in the precision of gene transfer as well as the source and means of introduction of new traits (George et al, 2000; Nigel and Peter, 2000).

TABLE 1: Comparison of conventional breeding and GMO.

\begin{tabular}{|c|c|c|}
\hline & Genetic Engineering & Conventional Breeding \\
\hline Gene Pool & Unlimited & Usually limited to relatives within species (except with wide crosses) \\
\hline $\begin{array}{l}\text { Number of } \\
\text { inserted genes }\end{array}$ & $\begin{array}{l}\text { Usually one or few } \\
\text { known genes }\end{array}$ & $\begin{array}{l}\text { Many blocks of genes, usually of unknown identity. Genes of } \\
\text { interest are transferred together with clusters of tightly linked genes } \\
\text { (genetic drag). }\end{array}$ \\
\hline $\begin{array}{l}\text { Location } \\
\text { genes }\end{array}$ & $\begin{array}{l}\text { Random into the } \\
\text { recipient genome }\end{array}$ & Usually, genes remain in locations in which they evolved \\
\hline $\begin{array}{l}\text { Speed and } \\
\text { Accuracy }\end{array}$ & $\begin{array}{l}\text { Relatively fast detailed } \\
\text { knowledge } \\
\text { molecular level of } \\
\text { inserted gene(s) }\end{array}$ & $\begin{array}{l}\text { Relatively slow requiring many back cross generations to give } \\
\text { desired phenotype. Genes of both parents are mixed with little } \\
\text { molecular knowledge on final outcome }\end{array}$ \\
\hline
\end{tabular}

Source: George et al, 2011

Conventional breeding is better suited for improving many traits simultaneously, or improving traits controlled by many genes, or traits for which the controlling gene has not been identified. It is also relatively inexpensive, technically simple, and free of government regulation. The major limitations of conventional methods derive from the limitations of the sexual process itself, and include constraints on the amount of genetic variation available within the crop (the gene pool) and the fact that all traits differing between the parents are subject to segregation, and thus large populations and multiple generations of selection are required to identify rare individuals that combine the best qualities of both parents. In addition, sexual methods are useless for improving crops that are sexually sterile, such as banana.

The advantages of genetic engineering result mainly from the ability to circumvent the shortcomings of sexual reproduction. Hence, the gene pool is unbounded. Improvement affects only the targeted trait (no segregation), so there is less need for large populations and multiple generations of selection. And, sterile and vegetative propagated crops are as readily treatable by this approach as fertile crops. Likewise, the limitations of genetic engineering are complemented by the strengths of conventional methods, in that the new technology can usually target only simple, single-gene traits; it is expensive and technically demanding; and it is regulated by government agencies(Richard,2004).

\subsection{Benefits of GMO's}

There is a wide range of existing and emerging problems related to food security that can be tackled by a range of crop technologies (FAO, 2010). Key areas include pest and disease control, salt and drought-tolerance, crop yield and quality, and the sustainability and environmental impact of crop production (Jacobsen et al, 2013). There are certain benefits associated with growing GM crops as compared to the traditional crops. The various benefits that have observed with the use of GMOs are listed in the succeeding paragraphs.

\subsubsection{Pest resistance}

Crop losses due to pests mean a huge financial loss to farmers. There is a growing concern amongst the various consumers that crops treated with pesticides are not safe for human use and have certain ill-effects on the human health. GM crops can certainly reduce this trend and chemical pesticides can be reduced to a great extent (Waris 
et al, 2012). Bt cotton is an example (Mike et al, 2003).

\subsubsection{Herbicide tolerance}

In certain crops, removing the weeds by physical means such as tilling is not much feasible and so generally it is preferred by the farmers to kill the herbicides through various herbicide sprays, which is both an expensive and a time-consuming activity(Waris et al,2012). Therefore, GM crops are beneficial to this extent in that they can be grown for herbicide tolerant trait and avoid the herbicidal sprays, Examples include soybean and maize.

\subsubsection{Disease resistance}

Scientists all across the globe are working to protect the plant from certain viruses, fungi and bacteria that are responsible for many plant diseases. Genetic engineering can be a hope towards making disease free plants (Lynn et al., 2001; and Scorza et al., 2001). For example transgenic approaches have been used to Combat Fusarium Head Blight in Wheat and Barley.

\subsubsection{Drought tolerance/ salinity tolerance}

It has been estimated that the world production will double by 2050 and as this continues to happen, more land will be utilized for housing as compared to food production. In these circumstances, creating plants that can be resistant and tolerant to drought or high salt content in soil and groundwater will help in increasing the production of crops in the already available area (Zhang and Blumwald, 2001). For example, transgenic tomato plants accumulate salt in foliage but not in fruit and the per oxides activity of desiccation tolerant loblolly pine somatic embryos have been demonstrated.

\subsubsection{Overcoming malnutrition in developing countries}

The third world countries present an ugly picture of malnourishment. The people living in the third world countries mostly rely on single crop For meeting their food requirements and Researchers from the Swiss Federal Institute of Technology's Institute for Plant Sciences inserted genes from a daffodil and a bacterium into rice plants to produce "golden rice," which has sufficient beta-carotene to meet total vitamin A requirements in developing countries with rice-based diets(Wieczorek,2003).So Through the use of genetic engineering, rice can be genetically engineered so as to add additional vitamins and thus many nutrient deficiencies could be overcome. For example, many people suffer from blindness due to vitamin A deficiency.

\subsubsection{Improved nutritional value}

Genetic engineering has allowed new options for improving the nutritional value, flavor, and texture of foods. Transgenic crops in development include soybeans with higher protein content, potatoes with more nutritionally available starch and an improved amino acid content, beans with more essential amino acids, and rice with the ability produce beta-carotene, a precursor of vitamin A(Wieczorek,2003).

\subsubsection{Better flavor}

Flavor can be altered by enhancing the activity of plant enzymes that transform aroma precursors into flavoring compounds. Transgenic peppers and melons with improved flavor are currently in field trials (Wieczorek, 2003).

\subsubsection{Environmental benefits}

When genetic engineering results in reduced pesticide dependence: less will be pesticidal residues on foods, reduce pesticide leaching into groundwater, and minimize farm worker exposure to hazardous products. With $B t$ cotton's resistance to three major pests, the transgenic variety now represents half of the U.S. cotton crop and has thereby reduced total world insecticide use by 15 percent!(Wieczorek,2003).

\subsubsection{Carbon sink and climate change}

The issue of global warming and climate change is a big challenge for all humanity in the globe. The deforestation rate, industrial activity, growing transportation and land use changes contribute the great percentage of greenhouse gases in the environment. The use of GM trees especially for carbon sequestration might solve this burning issue (Asante, 1999).

\subsection{Production trend of GMO's}

The cultivation of biotech crops has grown at a fast speed since their commercial introduction in the mid-1990s. 2015 is the 20th year of commercialization of biotech crops. From the initial planting of1.7 million hectares in 1996 to 179.7 million hectares in 2015 , biotech crops are considered as the fastest adopted crop technology in the history of modern agriculture (Pocket, 2016).

In 2015, approximately 18 million farmers planted biotech crops in 28 countries, wherein over 54\% or about 97.1 million hectares were planted by small and resource poor farmers from developing countries. The highest increase in any country, in absolute hectare age growth was Brazil with 2 million hectares. So in general, during the period of 1996 to 2015, biotech crops have been successfully grown in accumulated hectare age of 1.96 billion hectares (4.85 billion acres) (Clive, 2015). 


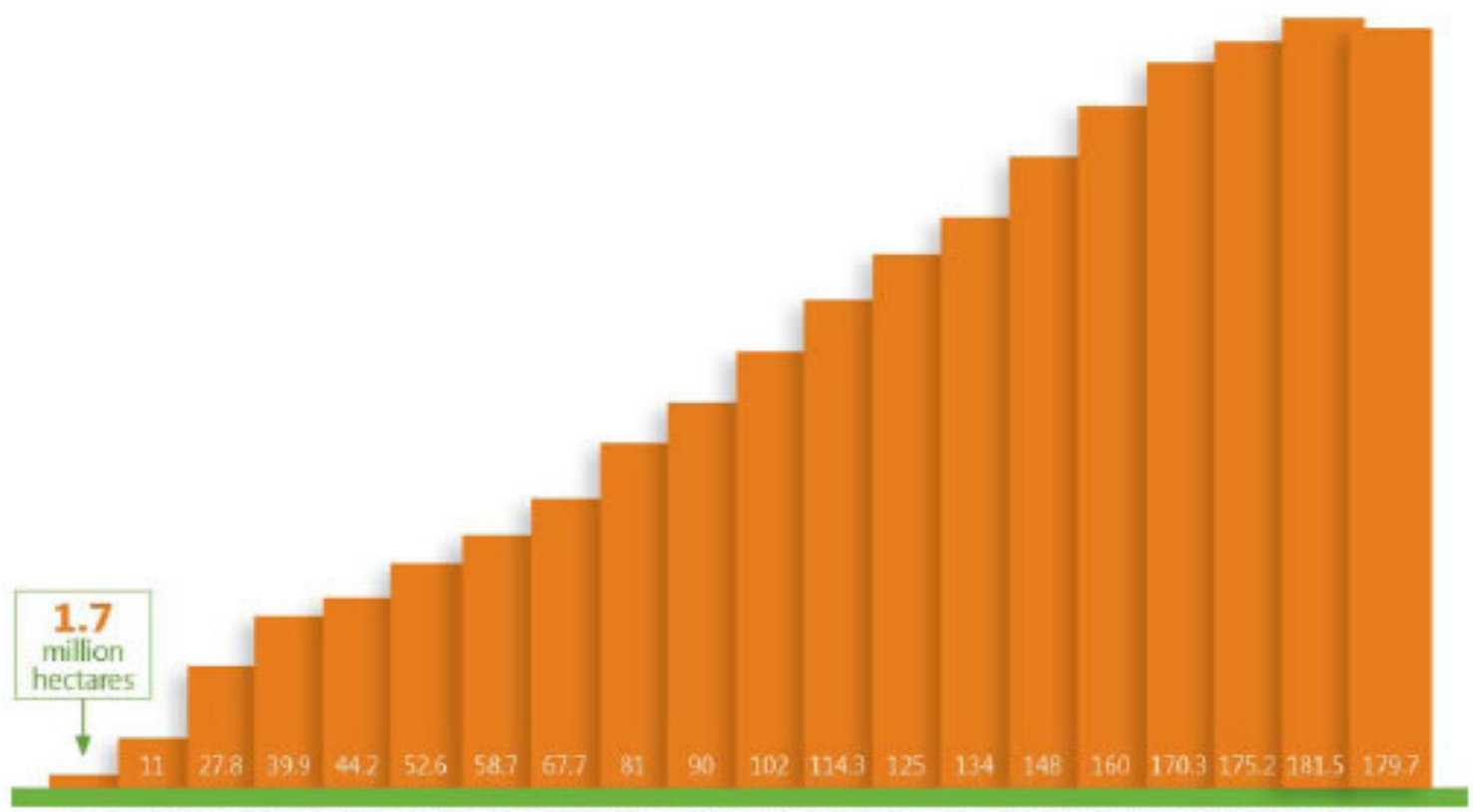

19961997199819992000200120022003200420052006200720082009201020112012201320142015

Figure 1. Global Area of Biotech Crops, 1996 to 2015 (million hectares).

Source Clive James 2015.

\subsubsection{Distribution of Biotech Crops in Industrial and Developing Countries}

In 2015 , more than half $(54 \%)$ of the global biotech crop area of 179.7 million hectares was grown in 20 developing countries. In 2015, year-to-year growth was higher in developing countries at 0.9 million hectares $(1 \%)$ than in industrial countries which were reduced by $3 \%$ (2.7 million hectares). This is attributed to the increase in soybean plantings in Brazil and Argentina, as well as cotton plantings in Pakistan, Myanmar, and Sudan. Thus year-to-year growth was significantly faster in developing countries in 2015 and maintained a larger share of global biotech crops at $54 \%$ compared with only $46 \%$ for industrial countries (Pocket, 2016).

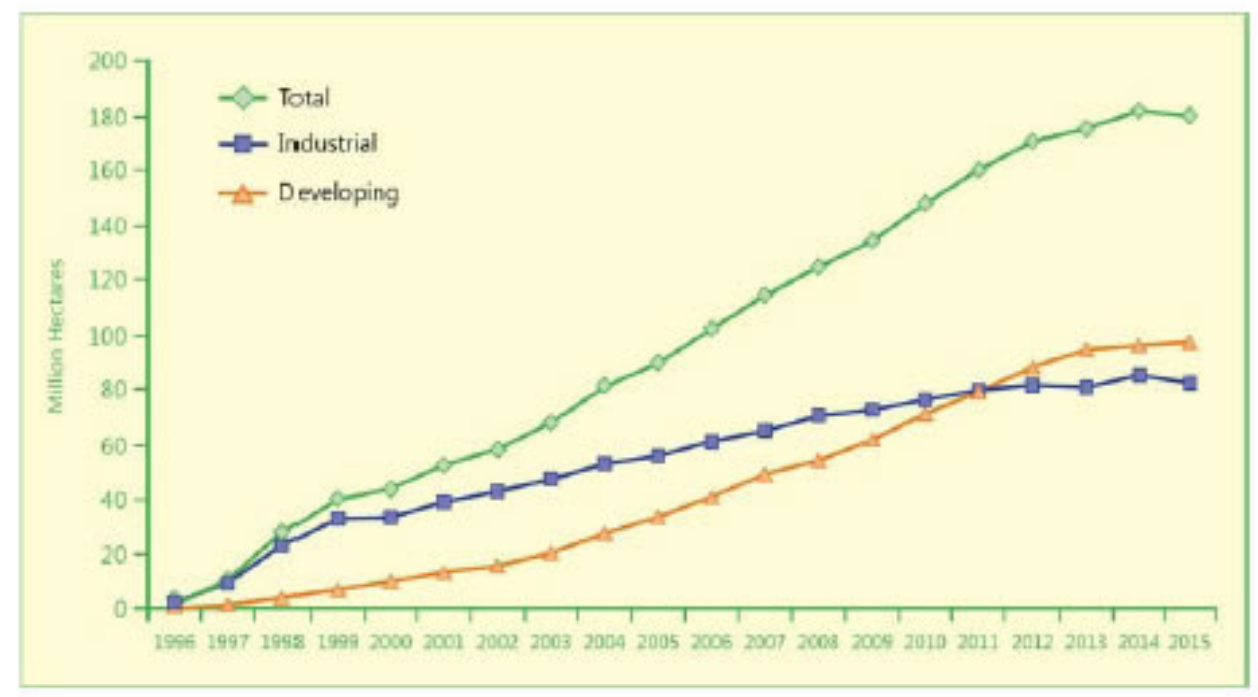

\section{Figure 2. Global Area of Biotech Crops, 1996 to 2015: Industrial and Developing Countries (Million Hectares)}

Source: Clive James 2015.

Biotech crops were grown commercially in all six continents of the world. Of the 28 countries planting biotech crops in 2015, 19 countries planted 50,000 hectares or more to biotech crops. These mega-countries include the USA, Brazil, Argentina, India, Canada, China, Paraguay, Pakistan, South Africa, Uruguay, Bolivia, Philippines, Australia, Burkina Faso, Myanmar, Mexico, Spain, Colombia, and Sudan (Pocket, 2016). 
In USA, the speed with which GM crops have spread has been impressive, since large-scale adoption began in 1996 (Enriquez, 2001). According to an update taken in 2007 on US agriculture, the proportion of GM to nonGM crops were $73 \%$ for maize, $87 \%$ for cotton, and $91 \%$ for soybean (USDA, 2007).On the other hand, adoption has been very slow in Europe due to strong public opposition. The opposition has been so severe, that in the EU only 114,500 ha of arable land is grown with Bt maize as the only GM crop, mostly in Spain (James, 2011 ), i.e., approximately $0.01 \%$ of the European agricultural area.

\subsubsection{Major Genetically Modifies Crops in the world}

Because major exporting countries have led their adoption, biotech crops represent a substantial share of key agricultural commodities (maize, soybeans, cotton and canola) which are broadly traded in international markets (James, 2012; and Kalaitzandonakes,2006).

To provide a global perspective of the status of biotech crops, the global adoption rates as a percentage of the respective global areas of the four principal crops - soybean, cotton, maize, and canola, is presented below.

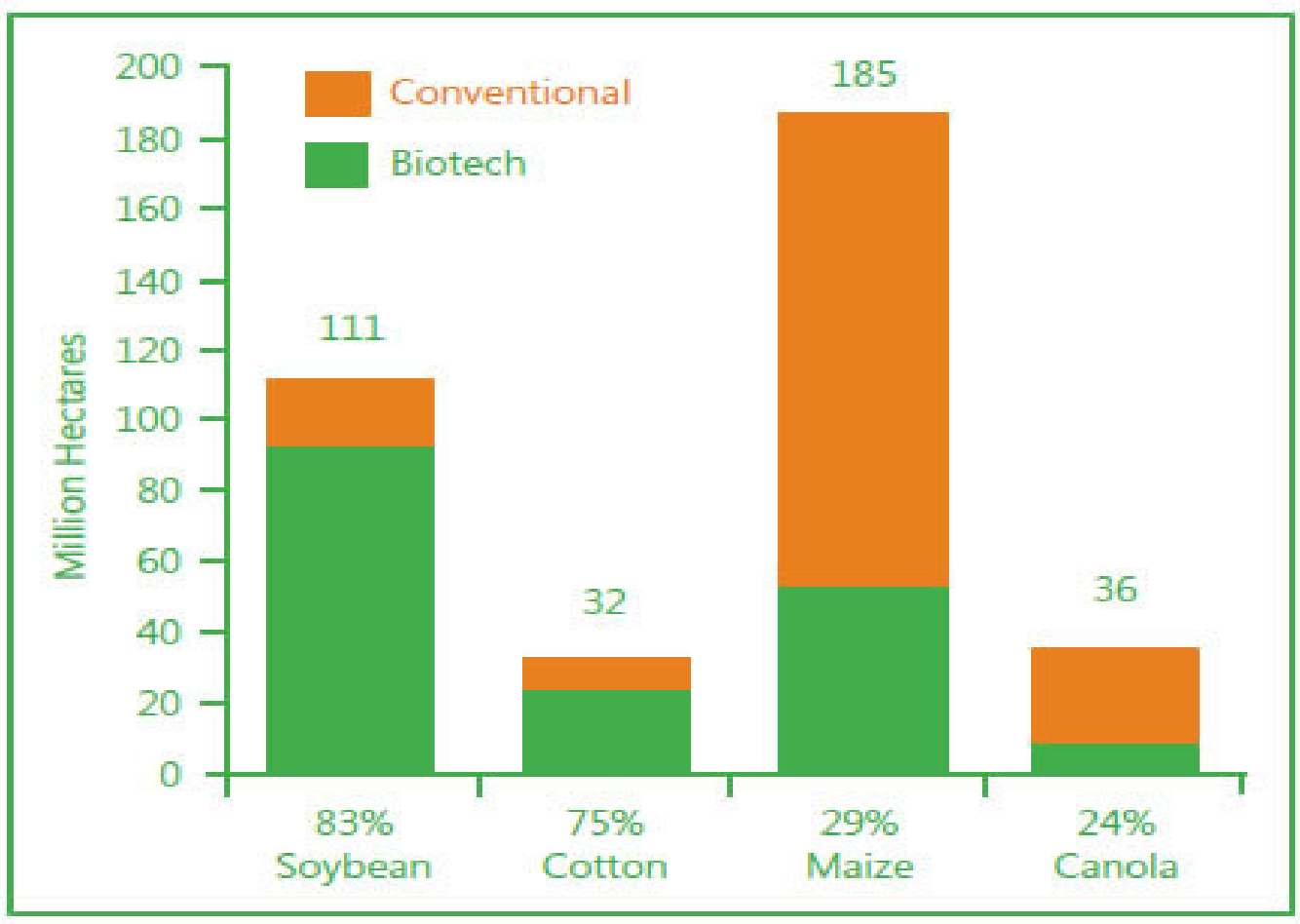

Figure 3. Biotech Crop Area as \% of Global Area of Principal Crops, 2015 (Million Hectares)

\section{Global Hectarages Data for 2015 (FAO, 2013) \\ Source: Compiled by Clive James, 2015.}

In $2015,83 \%$ (92.1 million hectares) of the 111 million hectares of the soybean planted globally were biotech (Figure 3). Biotech cotton was planted to 24 million hectares, which is $78 \%$ of the global cotton hectare of the 185 million hectares of global maize planted in $2015,29 \%$ or 53.6 million hectares were biotech maize. Finally, herbicide tolerant biotech canola was planted in 8.5 million hectares or $24 \%$ of the 36 million hectares of canola grown globally in 2015. If the global areas (conventional and biotech) of these four crops are combined, the total area is 364 million hectares, of which $49 \%$ or 179.7 million hectares were biotech (Pocket, 2016).

\subsection{Potential risks linked to genetically modified food}

Although there are positive aspects of the use of GMOs in the cases where it is superior to conventional breeding, Much has been said about potential risks of genetic engineering technology, but so far there is little evidence from scientific studies that these risks are real(Wieczorek,2003).

\subsubsection{Risk of food allergy}

Proteins obtained due to genetic modifications are thought to carry an allergizing potential if its sequence is homologous to another, defined allergen, inducing unfavorable immune body reactions(Marta et al, 2013) Allergenicity has been demonstrated in transgenic soybeans due to the transfer of a major food allergen from Brazil nuts (Nordlee et al, 1996). Scientists believe that the food allergens are found only in a few defined sources (peanut and other grain legumes, shellfish, tree nuts, etc.), Moreover, allergenicity occurs when these 
food allergens are present in large proportions in the food and the individuals are sensitized to them over time to cause any adverse effects. Thus, it is highly unlikely for new allergens to be introduced into the food supply from GM plants (Smita, 2013).

\subsubsection{Transfer of Antibiotic Resistance Gene to Microbes and Reduced Efficacy of Antibiotic Therapy}

Public is also concerned about the potential risks associated with gene transfer from plants to microbes. It is speculated that the consumption of GM foods containing antibiotic resistance marker gene by humans and animals may lead to transfer of these genes from GM food to micro flora in the gut of humans and animals or to the pathogens in the environment transforming them into strains that are resistant to antibiotic therapy (Kaeppler, 2000). Biotechnology scientists, however, are of the opinion that the gene used to develop GM plants currently in the market is safe for use because there is no evidence of allergenicity or toxicity related to it. Moreover, humans are also susceptible to consuming several kanamycin resistant bacteria that occur naturally in the environment (Smita, 2013).scientists have also developed nonresistance based selectable marker genes such as green fluorescent protein encoding gene (Gfp) and $\beta$-glucuronidase gene (Uid A) by looking to the views of the public (Jefferson,1987; and Kaeppler et al,2000).

\subsubsection{Development of New-Line Microbial Strains}

The ability of GM plants to create new toxic organisms. It is speculated that some non pest microbial strains may acquire pathogenic trait by gene flow from GM plants (Kaeppler, 2000)

\subsubsection{Uncertainties about Nutritional Status}

Critics of GM crops have raised various concerns about the potential of golden rice to combat vitamin A deficiency. In 2005, a team of researchers at Syngenta have produced a variety of golden rice, called "Golden rice 2 ," which produces twenty-three times more carotenoids than the previous golden rice(up to 37 $\mu \mathrm{g} / \mathrm{g}$ ) (Smita, 2013).

\subsubsection{Environmental and Ecological Concerns}

Large-scale cultivation of GM plants expressing viral and bacterial genes and their release into the environment is considered to be a threat and called as "genetic pollution" by the critics; The risk of a Transgene spreading in the environment is related to the likelihood for out-crossing, horizontal gene transfer, and the phenotype imparted by the gene(Snow andPalma,1996).some of the risks related to environment are: Transgene Escape to Wild-Type Plants, Generation of Super weeds, Development of Tolerance to Target Herbicide, Loss of Biodiversity, Contamination of Soil and Water (Smita, 2013).

\subsubsection{Ethical Issues}

Certain groups of public, including religious bodies, find it very unethical or inhumane to introduce human or animal genes into plants (Whitman, 2000); they see it as an unnatural way of producing foods.

\subsubsection{Labeling and Segregation of GM Foods}

The public has always lived with food risks, but in the last few decades, they have become concerned about the contents in GM foods (Whitman, 2000; and Glick and Pasternak, 2003), So An open and transparent system of labeling regarding genetically - modified foods and ingredients, coupled with effective traceability mechanisms, is likely to provide the best basis for consumer choice regarding the consumption of genetically - modified foods (Susan et al, 2005).

\subsection{8. "Terminator" technology}

Most farmers in the USA and elsewhere buy fresh seeds each season, particularly of such crops as corn, green peppers, and tomatoes. Anyone growing hybrid varieties must buy new seeds annually, because seeds from last year's hybrids grown on the farm will not produce plants identical to the parent. This is serious issue among organic growers and in developing countries, where the practice of saving seeds is the norm for farmers who are not growing hybrid crops. Inclusion of "terminator" genes means that these farmers cannot take advantage of improvements brought about by genetic engineering without being brought into the economic cycle that profits the seed companies. Without profit incentive, however, these companies are unlikely to invest in improving crops (Wieczorek, 2003).

\subsection{Risk perceptions and Public Attitudes to GMO}

In a society where choice exists, people will not consume foods that they associate with some negative attribute. Consumer acceptance is conditioned by the risk that they perceive from introducing food into their consumption habits processed through technology that they hardly understand (Bawa and Anilakumar, 2013). Some early studies found that the risks of DNA technology were perceived as extremely unknown, with very negative consequences that were delayed in time and not directly observable (Savadori et al, 2004).On a survey conducted in UK in 2003,responses suggest that attitudes to GM food in aggregate are clearly skewed towards the negative and also most people felt that the risks of GM food outweigh the benefits. 


\section{People's opinionon benefit and risk of GM food}

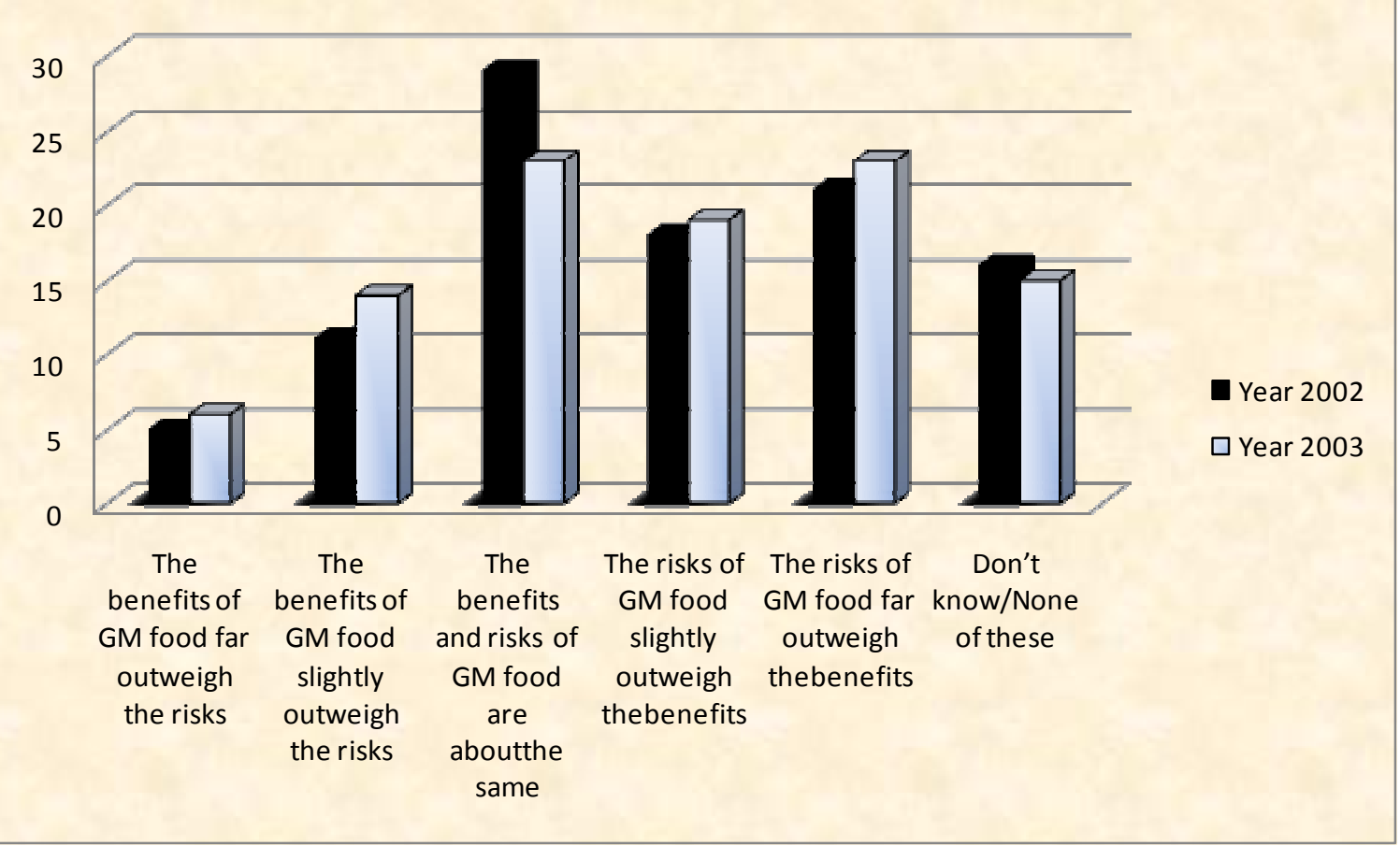

Fig 4. People's opinion on benefit and risk of GM food

Source: UEA/MORI GM Food Survey 2003 (Weighted dataset, n=1,363); UEA/MORI Risk

Survey 2002 (Weighted dataset, $n=296$ ).

Quite obviously, it is possible for a person to have a negative opinion about genetic modification of foods at the same time be convinced that a particular genetically modified food is a good product. An individual consumer may still personally buy the critically evaluated genetically modified food because it has other attributes that make it attractive, such as its price, packaging, availability, or the convenience of its preparation. The complexity of these interrelating factors helps explain some of the individual differences in consumer behaviors associated with the actual purchase of genetically modified foods (Frewer, et al.2004).

In a study conducted in Spain, the main conclusion was that the introduction of GM food into agro-food markets should be accompanied by adequate policies to guarantee consumer safety. These actions would allow a decrease in consumer-perceived risk by taking special care of the information provided, especially, relating to health because the most influential factor in consumer-perceived risk from these foods is concern about health (Martinez et al.2009).

\section{SUMMARY AND CONCLUSION}

Since agriculture started Peoples were trying to select the best varieties, cross-fertilize and then further selecting to improve the domesticated crops. Through process, plant improvement by the use of biotechnology and genetic engineering by manipulating existing genetic resources started. This technology offers breeders access a short way of improving domesticated plants, mainly because it can bypass biological barriers for recombination and genetic exchange across unrelated species by creating Transgenes. The first genetically modified (GM) plant was produced in 1983, using an antibiotic-resistant tobacco plant, since then a number of food species in which a genetically modified version exists. Some of the foods that are available in the market include cotton, soybean, canola, potatoes, eggplant, strawberries, corn, tomatoes, lettuce, cantaloupe, carrots etc.

The cultivation of biotech crops since their commercial introduction in the mid-1990 has grown at a fast speed and has become the fastest adopted crop technology in the history of modern agriculture. The various benefits of Genetically-modified foods have the potential to solve many of the world's hunger and malnutrition problems and to help protect and preserve the environment by increasing yield and reducing reliance upon chemical pesticides and herbicides; And in contrary much has been said about potential risks of genetic engineering technology, some major concerns about the safety, environmental and ecological risks and health hazards; but so far there is little evidence from scientific studies that these risks are real. And many studies suggest that attitudes to GM food in aggregate are clearly skewed towards the negative and also most people felt that the risks of GM food outweigh the benefits. Even though Individual consumer may feel negative about this 
technology they still personally buy the critically evaluated genetically modified food because it has other attributes that make it attractive, such as its price, packaging, availability, or the convenience of its preparation.

\section{PROSPECTS/ FUTURE LINE OF WORK}

Genetic engineering is the unavoidable wave of the future and we cannot afford to ignore a technology that has such enormous potential benefits; Future envisions that applications of GMOs are diverse and include drugs in food, bananas that produce human vaccines against infectious diseases such as Hepatitis B, metabolically engineered fish that mature more quickly, fruit and nut trees that yield years earlier, foods no longer containing properties associated with common intolerances, and plants that produce new biodegradable plastics with unique properties

There are gaps that have to be filled for this technology to be a success: such as

$>$ To test and eliminate the potential risks of GM food crops under controlled condition before their introduction.

$>$ Informing the public about the food production and the safety used in developing GM crops so they can form opinions based on facts, not fear.

$>$ Considerable effort need to be directed towards understanding people's attitudes towards this gene technology (what do the people need more).

$>$ Scientists should first finish probing for desirable trait from more of related species before going for another organism so as to reduce the public's concern.

$>$ At the same time there is lack of trust in institutions and institutional activities regarding GMOs and the public perceive that institutions have failed to take account of the actual concerns of the public as part of their risk management activities; so institutions should make their primary goal to serve the public not money.

\section{REFERENCES}

B. R. Glick and J. J. Pasternak, Molecular Biotechnology: Principles and Applications of Recombinant DNA, ASM Press, Washington, DC, USA, 2003.

Bawa, A.S. and 2013, K.R., 2013. Genetically modified foods: safety, risks and public concerns-a review. Journal of food science and technology, 50(6), pp.1035-1046.

Bower, R. and Birch, R.G., 1992. Transgenic sugarcane plants via microprojectile bombardment. The Plant Journal, 2(3), pp.409-416.

Christou, P., 1992. Genetic transformation of crop plants using microprojectile bombardment. The Plant Journal, 2(3), pp.275-281.

Christou, P., Ford, T.L. and Kofron, M., 1991. Production of transgenic rice (Oryza sativa L.) plants from agronomically important indica and japonica varieties via electric discharge particle acceleration of exogenous DNA into immature zygotic embryos. Nature Biotechnology, 9(10), pp.957-962.

Christou, P., McCabe, D.E., Martinell, B.J. and Swain, W.F., 1990. Soybean genetic engineering-commercial production of transgenic plants. Trends in Biotechnology, 8, pp.145-151.

Clive J. Global status of commercialized Biotech/GM crops.ISAAA Briefs 43. Ithaca: International Service for the Acquisition of Agri-biotech Applications; 2011

Dahleen, L.S., Okubara, P.A. and Blechl, A.E., 2001. Transgenic approaches to combat Fusarium head blight in wheat and barley. Crop Science, 41(3), pp.628-637.

Domingo, J.L. and Bordonaba, J.G., 2011. A literature review on the safety assessment of genetically modified plants.Environment International, 37(4), pp.734-742.

Ellis, D.D., McCabe, D., Russell, D., Martinell, B. and McCown, B.H., 1991. Expression of inducible angiosperm promoters in a gymnosperm, Piceaglauca (white spruce).Plant molecular biology, 17(1), pp.1927.

Enriquez, J., 2001. Green biotechnology and European competitiveness.TRENDS in Biotechnology, 19(4), pp.135-139.

Fitch, M.M., Manshardt, R.M., Gonsalves, D., Slightom, J.L. and Sanford, J.C., 1990. Stable transformation of papaya via microprojectilebombardment.Plant Cell Reports, 9(4), pp.189-194.

Frewer, L., Lassen, J., Kettlitz, B., Scholderer, J., Beekman, V. and Berdal, K.G., 2004.Societal aspects of genetically modified foods.Food and Chemical Toxicology, 42(7), pp.1181-1193.

Fromm, M.E., Morrish, F., Armstrong, C., Williams, R., Thomas, J. and Klein, T.M., 1990.Inheritance and expression of chimeric genes in the progeny of transgenic maize plants.Nature Biotechnology, 8(9), pp.833839.

Gabol, W.A., Ahmed, A., Bux, H., Ahmed, K., Mahar, A. and Laghari, S., 2012. Genetically modified organisms (GMOs) in Pakistan.African Journal of Biotechnology, 11(12), pp.2807-2813.

Gachet, E., Martin, G.G., Vigneau, F. and Meyer, G., 1998. Detection of genetically modified organisms (GMOs) 
by PCR: a brief review of methodologies available. Trends in food science \& Technology, 9(11), pp.380388.

Hagio, T., Blowers, A.D. and Earle, E.D., 1991. Stable transformation of sorghum cell cultures after bombardment with DNA-coated microprojectiles. Plant cell reports, 10(5), pp.260-264.

Halford, N.G. and Shewry, P.R., 2000. Genetically modified crops: methodology, benefits, regulation and public concerns. British Medical Bulletin, 56(1), pp.62-73.

Hamstra, A., 1998. Public opinion about biotechnology: A survey of surveys. European Federation of Biotechnology, Task Group on Public Perceptions of Biotechnology.

Holst-Jensen, A., 2009. Testing for genetically modified organisms (GMOs): Past, present and future perspectives. Biotechnology advances, 27(6), pp.1071-1082.

Hull, R., Tzotzos, G.T. and Head, G., 2009. Genetically modified plants: assessing safety and managing risk. Academic Press.

Jacobsen, S.E., Sørensen, M., Pedersen, S.M. and Weiner, J., 2013. Feeding the world: genetically modified crops versus agricultural biodiversity. Agronomy for sustainable development, 33(4), pp.651-662.

James C (2011) Global status of commercialized biotech/GM crops: 2011. ISAAA Brief No. 43. ISAAA, Ithaca, NY

James, C., 2012. Global Status of Commercialized Biotech/GM Crops: ISAAA Brief No.43-2012. ISAAA: Ithaca, NY.

James, C., 2015. 20th Anniversary (1996 to 2015) of the global commercialization of biotech crops and biotech crop highlights in 2015. ISAAA Brief, 51.

Jefferson, R.A., Kavanagh, T.A. and Bevan, M.W., 1987. GUS fusions: beta-glucuronidase as a sensitive and versatile gene fusion marker in higher plants. The EMBO journal, 6(13), p.3901.

Job, D., 2002. Plant biotechnology in agriculture.Biochimie, 84(11), pp.1105-1110.

Johnson SR. Quantification of the impacts on US Agriculture of Biotechnology-Derived Crops Planted in 2006. Washington DC: National Centre for Food and Agricultural Policy; 2008.

Kaeppler, H.F., Menon, G.K., Skadsen, R.W., Nuutila, A.M. and Carlson, A.R., 2000. Transgenic oat plants via visual selection of cells expressing green fluorescent protein. Plant cell reports, 19(7), pp.661-666.

Kalaitzandonakes, N., 2006. Cartagena Protocol: A New Trade Barrier?.Regulation, 29(2), pp.18-25.

Kramkowska, M., Grzelak, T. and Czyzewska, K., 2013. Benefits and risks associated with genetically modified food products. Annals of Agricultural and Environmental Medicine, 20(3).

Manshardt, R., 2004. Crop Improvement by Conventional Breeding or Genetic Engineering: How Different Are They?.

Martinez-Poveda, A., Molla-Bauza, M.B., del Campo Gomis, F.J. and Martinez, L.M.C., 2009. Consumerperceived risk model for the introduction of genetically modified food in Spain.Food Policy, 34(6), pp.519528.

McCabe, D.E. and Martinell, B.J., 1991. Particle gun transformation applied to cotton. In Proceedings of III International Congress of Plant Molecular Biology.

McCown, B.H., McCabe, D.E., Russell, D.R., Robison, D.J., Barton, K.A. and Raffa, K.F., 1991. Stable transformation of Populus and incorporation of pest resistance by electric discharge particle acceleration.Plant Cell Reports, 9(10), pp.590-594.

Mendelsohn, M., Kough, J., Vaituzis, Z. and Matthews, K., 2003. Are Bt crops safe?.Nature biotechnology, 21(9), pp.1003-1009.

Miles, S., Ueland, Ø. and Frewer, L.J., 2005.Public attitudes towards genetically-modified food.British Food Journal, 107(4), pp.246-262.

Nordlee, J.A., Taylor, S.L., Townsend, J.A., Thomas, L.A. and Bush, R.K., 1996. Identification of a Brazil-nut allergen in transgenic soybeans.New England Journal of Medicine, 334(11), pp.688-692.

Opabode, J.T., 2006. Agrobacterium-mediated transformation of plants: emerging factors that influence efficiency. Biotechnology and Molecular Biology Reviews, 1(1), pp.12-20.

Owusu, R.A. and Fondsmondial pour la nature (United Kingdom), 1999. GM technology in the forest sector: a scoping study for WWF. World Wide Fund for Nature.

Pingali, P. and Raney, T., 2005. From the Green Revolution to the Gene Revolution: how will the poor fare?.Mansholt publication series-Volume 4, p.407.

RastogiVerma, S., 2013.Genetically modified plants: public and scientific perceptions.ISRN biotechnology, 2013.

Rivera, A.L., Gómez-Lim, M., Fernández, F. and Loske, A.M., 2012. Physical methods for genetic plant transformation. Physics of life reviews, 9(3), pp.308-345.

Savadori, L., Savio, S., Nicotra, E., Rumiati, R., Finucane, M. and Slovic, P., 2004. Expert and public perception of risk from biotechnology.Risk Analysis, 24(5), pp.1289-1299.

Scorza, R., Callahan, A., Levy, L., Damsteegt, V., Webb, K. and Ravelonandro, M., 2001.Post-transcriptional 
gene silencing in plum pox virus resistant transgenic European plum containing the plum pox potyvirus coat protein gene.Transgenic Research, 10(3), pp.201-209.

Serres, R., McCown, B., McCabe, D., Stang, E., Russell, D. and Martinell, B., 1990. Stable genetic transformation of cranberry using electric discharge particle acceleration.HortScience, 25(9), pp.1130-1130.

Sharma, H.C., Crouch, J.H., Sharma, K.K., Seetharama, N. and Hash, C.T., 2002. Applications of biotechnology for crop improvement: prospects and constraints. Plant Science, 163(3), pp.381-395.

Singh, O.V., Ghai, S., Paul, D. and Jain, R.K., 2006. Genetically modified crops: success, safety assessment, and public concern.Applied microbiology and biotechnology, 71(5), pp.598-607.

Snow, A.A. and Palma, P.M., 1997. Commercialization of transgenic plants: potential ecological risks. BioScience, 47(2), pp.86-96.

Thu, T.T., Mai, T.T.X., Dewaele, E., Farsi, S., Tadesse, Y., Angenon, G. and Jacobs, M., 2003. In vitro regeneration and transformation of pigeonpea [Cajanuscajan (L.) Millsp].Molecular Breeding, 11(2), pp.159-168.

UEA/MORI GM Food Survey 2003 (Weighted dataset, n=1,363); UEA/MORI Risk Survey 2002 (Weighted dataset, $n=296)$.

USDA (2007) National Agricultural Statistics Service (NASS). Agricultural Statistics Board, US Department of Agriculture Acreage.

Vasil, V., Brown, S.M., Re, D., Fromm, M.E. and Vasil, I.K., 1991. Stably transformed callus lines from microprojectile bombardment of cell suspension cultures of wheat. Nature Biotechnology, 9(8), pp.743-747.

Whitman, D.B., 2000. Genetically modified foods: harmful or helpful?. CSA Discovery guides, pp.1-13.

Wieczorek, A., 2003. Use of Biotechnology in Agriculture--Benefits and Risks.

Zhang, H.X. and Blumwald, E., 2001. Transgenic salt-tolerant tomato plants accumulate salt in foliage but not in fruit. Nature biotechnology, 19(8), pp.765-768. 